$\begin{array}{ll}\text { Nama } & \text { : Nicole Doelitzsch Liang } \\ \text { Nrp } & : 130219070 \\ \text { KP } & : \text { B }\end{array}$

\title{
Tugas Perekonomian Indonesia
}

Citation : Tayibnapis, A. Z.; Wuryaningsih, L. E; Gora, R. (2019). Companies in Indonesia in the vortex of global economic disruption. Advances in Social Science, Education and Humanities Research, 308, 174-177. DOI: 10.2991/insyma-19.2019.45

\section{The Competitiveness of Indonesia's Companies in Facing Economic Disruption}

\section{Abstract}

To survive in the midst of global economic uncertainty, the best alternative for companies in Indonesia is by transforming their business and human resources, given that changes in business concepts are highly driven and patterned by advances in information technology that are exponentially increasing. Economic disruption era requires companies in Indonesia to always generate new values in all aspects so that performance can increase and the companies are able to survive in the market by gaining positive profits. This study is qualitative research with the interpretive paradigm, based on reality or the phenomenon that occurs. The findings were in the form of comprehensive analysis according to the primary and secondary data that the researchers have successfully explored.

\section{Introduction}

Throughout 2018, Various efforts to improve the ranking of ease of doing business in Indonesia are still restrained by exports and imports that have consistently tended to decline since 2015. Economic disruption era is expected to happen until 2020, business people in Indonesia are required to constantly renew, innovate, and create diversification so that they can survive in the market. The growing competition in the market faced by business people makes company leaders tend to make changes continuously where each element must be an important pillar in order to support the company's vision and mission, including optimizing the strategies that have been determined to obtain profit maximization. In reality, many companies in Indonesia still do not know what to do. Many companies are trying out the latest management systems to deal with the global economic disruption with an expectation that the companies will be sustainable and adaptive to the times. The implementation of quality Good Corporate Governance (GCG) enables the creation of added value for stakeholders, and in turn will create sustainable business success. GCG practices and value added creation are expected to meet three dimensions: compliance, conformance, and performance. For the need of employee engagement, companies also need a clear framework so that the direction of the organization becomes clear and measurable, and the execution of the strategies becomes appropriate and sustainable.

\section{Research Method}


This research belongs to the qualitative category with the interpretive paradigm, to study the phenomena and the methods used in the research and then interpret findings. The purpose of the interpretative approach is to analyze the reality of global economic uncertainty and the fluctuations of the IDR (Indonesian Rupiah) against the US Dollar and their effect on the lives of companies in Indonesia in order to survive in the market through the power of competitiveness. The researchers use primary data and secondary data to explore how business people perceive economic disruption and how business people save and shape their own reality so that they are familiar with the economic disruption. This qualitative research focuses on the results of interviews and observations on tourist destinations that are made as the research samples to see reality, study phenomena, and interpret findings in the field. Data analysis was carried out to obtain accurate and indepth results.

\section{Results and Discussions}

The workforce that is sought after by companies is data analysis and business intelligence, general digital or internet-based marketing and software programming experts. The development of the digital economy turns out to stimulate the search for new workers by prioritizing information technology skills. Seems like the quality of workforce development in Indonesia is not maximal, it's reflected in the Labor Development Index which only reached 60.81 in 2018. Many job opportunities are created by digital trends but most are informal and have no official legal status. The competitiveness of companies in Indonesia in facing economic disruption and industrial revolution 4.0 is very dependent on the ability to take advantage of changes along with technological advancement that has been increasing exponentially in order to survive, develop, and provide significant added value to all stakeholders. Important agendas in many companies are business transformation and human resource transformation. Companies in Indonesia that have succeeded in carrying out business and human resource transformation are PT. BNI, Tbk. and PT. Hartono Plantation Indonesia (HPI-Agro). The transformation process must be able to meet the basic principles of GCG, transparency, accountability, responsibility, independence, and fairness. More and more companies in Indonesia nowadays are implementing GCG not as a regulatory or something that is burden, but implementing them as part of the company's tools and guidelines in getting to know the business transformation process. Turns out, the implementation of GCG is able to encourage companies to continue to strive to create and introduce new values in the aspects of products, operations, and services that have an impact on improving company performance, and ultimately benefit stakeholders. Employee engagement is very important in companies that are currently in the vortex of global economic disruption. Employee engagement provides access for management to be able to improve the conditions of employees' say, stay, and strive through efforts to build high commitment and accommodate aspects of employee satisfaction with the company better, which in turn can be implemented into daily operational activities.

\section{Conclusion}

In facing economic disruption, competitive advantage has become a necessity for every company in Indonesia when the company wants to survive in the domestic and global markets through a massive transformation at all levels and business units operated as well as continuous innovation. Company leaders face very difficult challenges because of economic disruption. The leaders have to strive to be more adaptive in facing the future that is full of volatility, uncertainty, complexity, and ambiguity (VUCA), including being able to bring a positive aura 
to all employees. The implementation of GCG in companies proves to be able to increase company value, market value, culture value, the openness of information, effectiveness of the audit system, and risk control. 